\title{
Occurrence of lionfish, Pterois miles (Bennett, 1828) in the coast of Aegean Sea (Turkey): The northernmost dispersal record
}

\author{
Ege Denizi kıyılarında aslan balığının Pterois miles (Bennett, 1828) \\ bulunuşu: En kuzey kaydı
}

\section{Aytaç Özgül}

Abstract: Pterois miles (Bennett, 1828) is one of the worst aquatic invaders in history and its rapid dispersal in the Mediterranean Sea raise serious concerns for local communities. On August 2019, one specimen was caught by spear-fisher at depths of $15 \mathrm{~m}$ in Kokar Bay of Aegean Sea, Turkey. This occurrence represents the northernmost record of the species in the Aegean Sea.

Keywords: Pterois miles, devil firefish, alien species, Aegean Sea

Öz: Pterois miles (Bennett, 1828), tarihin en kötü istilacı türlerinden biridir ve Akdeniz'deki hızlı dağııımı yerel topluluklar için ciddi kaygılar doğurmaktadır. Ağustos 2019 tarihinde bir birey Ege Denizi'nde Kokar Koyu'nda bir zıpkıncı tarafından $15 \mathrm{~m}$ derinlikte yakalanmıştır. Bu kayit, günümüze kadar türün Ege Denizi'ndeki en kuzey kaydını temsil etmektedir.

Anahtar kelimeler: Pterois miles, aslan balığı, yabancı türler, Ege Denizi

\section{INTRODUCTION}

The number of alien species becoming major invasive threat has been increasing in the Aegean Sea remarkably. A potentially destructive Indo-Pacific species, Pterois miles (Bennett, 1828), have recently been introduced to the Mediterranean, which may unfavorably affect not only the structure and function of local ecosystems but also the socioeconomy, fishery, biodiversity and also even human health (Bilecenoğlu, 2018). P. miles is a species commonly found in the Indian Ocean and Red Sea (Froese and Pauly, 2019). They are usually found in reef fish communities (Green and Côté, 2009) and commonly found in water depths from 25 to $85 \mathrm{~m}$ on hard bottom, coral reefs and artificial substrate, sometimes found under ledges and hiding in crevices (Hare and Whitfield, 2003). They invade the Mediterranean from the Red Sea via the Suez Canal (Golani and Sonin, 1992).

Lionfish $P$. miles was recorded for the first time from the Mediterranean Sea at Haifa Bay in 1991 (Golani and Sonin, 1992), and later lionfish $P$. miles were reported from Lebanon coast (Bariche et al. 2013) and Cyprus coast (Evripidou, 2013) and then sighted in Turkey (Turan et al., 2014), Rhodes in Greece (Crocetta et al., 2015). Recently, several records were reported from the southern coast of Turkey indicating a westerly migration of the species towards the Aegean Sea
(Bilge et al., 2016; Yağlıoğlu and Ayaş, 2016; Turan et al., 2017). First observation of $P$. miles from the Aegean Sea was reported from Fethiye Bay in July 2015 and Dalyan coast in August 2015 (Turan and Öztürk, 2015). Nowadays it also reported in Lebanon (Azzurro et al., 2017), Cyprus (Jimenez et al., 2016), Greece (Crocetta et al., 2015; Dailianis et al., 2016), Tunisia (Azzurro et al., 2017; Karachle et al., 2017), Libya (Mabruk and Rizgala, 2019) and also Italy (Azzurro et al., 2017). And over the last years, the species has expanded towards the northeast Aegean Sea. Up to the present, a northernmost occurrence of the species from the Didim coast off Turkey (Yapıcl, 2018). This ichthyologic note presents the northernmost record, updating our present knowledge on the distribution of Lessepsian P. miles for the Aegean Sea.

\section{MATERIAL AND METHODS}

On 26 August 2019, a specimen of $P$. miles was captured by a spearfisher from Kokar Bay-lzmir at depth of $15 \mathrm{~m}$ on rocky bottoms. The specimen was having a total length (TL) of $144 \mathrm{~mm}$ captured at $38.13520 \mathrm{~N}$ and 26.60980 E (Figure 1). The water temperature was $20.5^{\circ} \mathrm{C}$. The specimen was identified based on the description provided by Golani et al. (2006). Fish were preserved in 10\% buffered formalin and 
deposited in the Ichthyological Collection of Ege University, Fisheries Faculty, under catalog numbers ESFM-PIS/2019003.

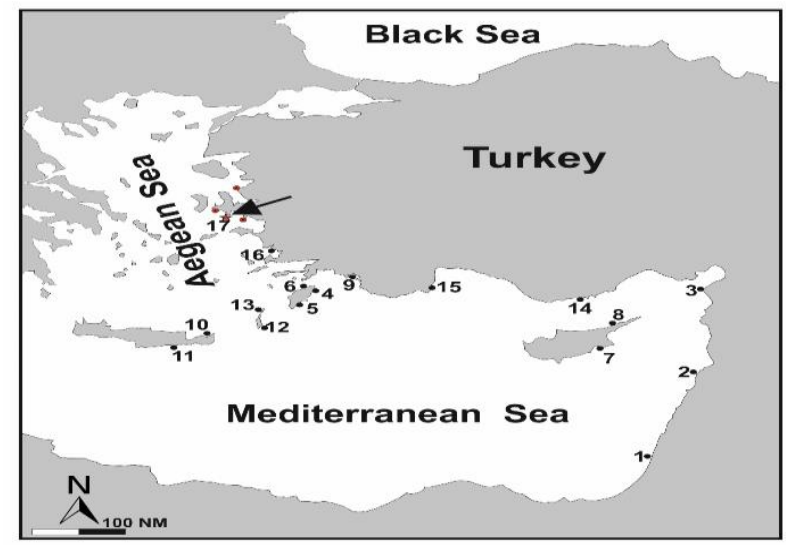

Figure 1. The distribution of $P$. miles occurrences in the Mediterranean Sea and, towards on the Aegean Sea (Red points indicated that underwater observation from spearfisher (Gökay Gülhep personal comm.)
Behind the tows, individuals were preserved in a plastic case with ice, then delivered to the laboratory, immediately. The total length, total weight, otolith length, otolith width and otolith weight of $L$. friesii $(n=213)$, A. kessleri $\quad(n=164), \quad G$. biscayensis $(n=50)$, S. solea $(n=25), L$. boscii $(n=17), L$. budegassa $(n=15)$ and $U$. scaber $(n=13)$ were measured. Total length (TL) and weight measurements were conducted in the laboratory to the nearest $0.1 \mathrm{~cm}$ and $0.01 \mathrm{~g}$, respectively. The otoliths (sagittae) were removed and measured under stereoscopic microscope to the nearest $0.1 \mathrm{~mm}(\mathrm{TL})$. The weight of otoliths (OW) were measured with $0.0001 \mathrm{~g}$ digital analytical balance precision scale. Lengths of sagittae (OL) were recorded as the greatest distance measured from the anterior tip to the posterior edge, parallel to the sulcus The width of sagitta (OWi) was determined by considering the greatest distance from the dorsal otolith edge to the ventral one, perpendicular to the sulcus (Harvey et al., 2000) (Figure 2).
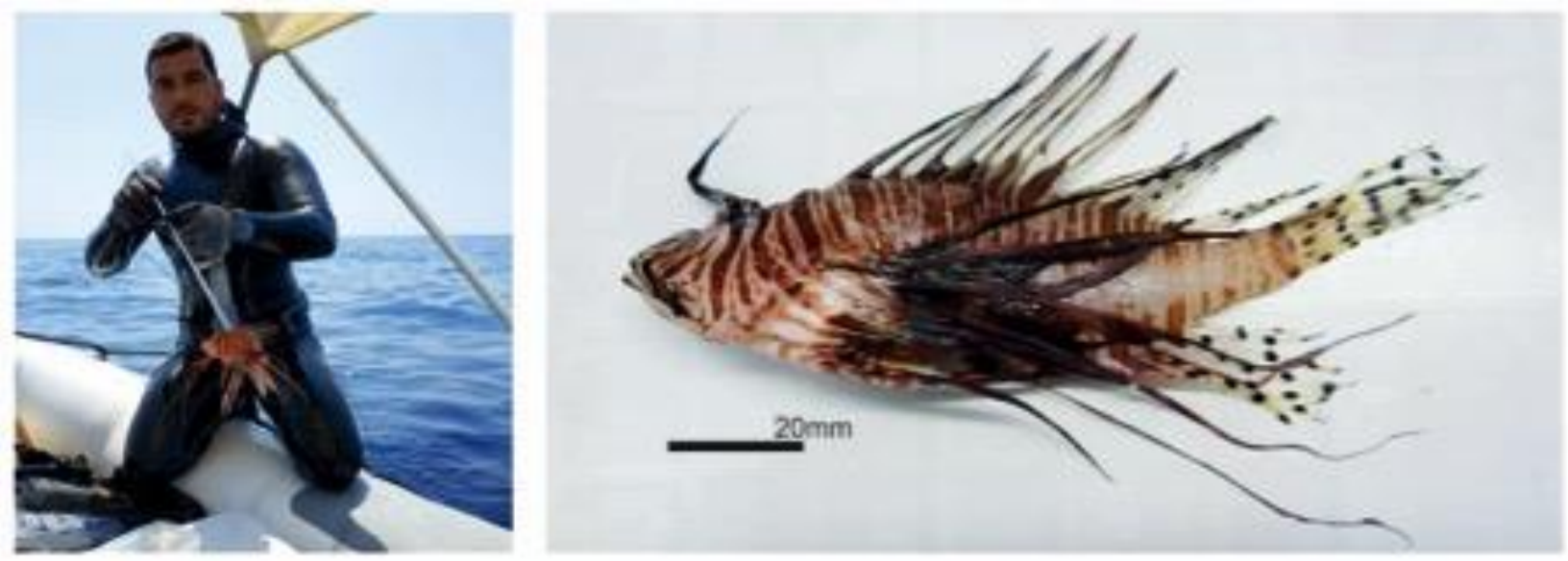

Figure 2. Pterois miles captured off the Kokar Bay in the Aegean Sea

\section{RESULTS}

The captured specimen was $144 \mathrm{~mm}$ in total length, its total body weight was $38.8 \mathrm{~g}$ (Table 1). It was identified as a $P$. miles based on a combination of morphological characters, morphometric measurements, meristic counts and colour, which were in total agreement with previous descriptions of the species by Golani and Sonin (1992). It was measured to the nearest millimeter, and some morphometric measurements were indicated in Table 1.

\section{DISCUSSION}

The presence of $P$. miles in the Aegean Sea was first reported in 2015 in Rhodes (Crocetta et al., 2015), Fethiye and Dalyan (Turan and Öztürk, 2015). It has been emphasized by many authors that the temperature of seawaters will rise northward in the following years (Poursanidis, 2015; Giovos et al., 2018). This study supports the accuracy of these ideas. $P$. miles is expected to be detected further north in the coming years. It is reported by the spearfisher that lionfish are sight and caught further north from the area where the fish in this study was caught (Gökay Gülhep, pers.comm.). According to spearfisher $P$ miles also has been sighted in Kokay Bay $(18 \mathrm{~m}$; September 2019), Sığacık Bay (17 m, September 2019) and also Foça (15 m, October 2018). These observations also indicate that $P$. miles are successfully and rapidly expanding from the Mediterranean coasts northward to the Aegean Sea. Its extension may be determined by sea temperature (Turan et al., 2016). In recent years, the increase in the distribution towards the northern Aegean Sea, and the records of smallest individuals indicate that it has strengthened the spread and started to be one of the established species. P.miles get high scores in risk analysis studies on lesepsian species on outhwestern coasts of Turkey (Filiz et al., 2017; Bilge et al., 2019). 
These studies drawn attention to the speed and seriousness of the invasion.

Table 1. Morphometric measurements in $\mathrm{mm}$ and as percentages of total length (\%TL), standard length (\%SL) meristic counts and weight in grams recorded in the specimen of Pterois miles from the Aegean Sea

\begin{tabular}{lcc}
\hline $\begin{array}{l}\text { Morphometric } \\
\text { measurements }\end{array}$ & $\mathbf{m m}$ & TL\% \\
\hline Total length & 144 & 100.0 \\
Standard length & 106 & 73.6 \\
Barbel length & 17 & 11.8 \\
Head length & 36 & 25.0 \\
Body depth & 38 & 26.4 \\
& & \\
Dorsal fin rays & \multicolumn{2}{c}{$10+$ XIII } \\
Pelvic fin rays & \multicolumn{2}{c}{$5+$ I } \\
Anal fin rays & \multicolumn{2}{c}{1 III } \\
Pectoral fin rays & \multicolumn{2}{c}{$15+$ II } \\
Caudal fin rays & \multicolumn{2}{c}{38.8} \\
Total weight (grams) & \multicolumn{2}{c}{} \\
\hline
\end{tabular}

Mediterranean seawater temperatures are steadily increasing, and alien species are spreading, causing community shifts and tropicalization (Lejeusne et al., 2010; Montefalcone et al., 2015) There are now >1000 alien species in the Mediterranean and the majority are thermophilic species that have entered the eastern basin through the Suez Canal (Katsanevakis et al., 2014). Recent enlargement of this canal coupled with sea surface warming is raising concerns that this problem will get worse. $P$. miles has been considered highly temperature-dependent (Dabruzzi et al., 2017), according to Kimball et al. (2004) P. miles unable to survive below $10^{\circ} \mathrm{C}$. However, Özgür-Özbek et al. (2017) reported that the $P$. miles continued feeding in low winter temperature $\left(14.9^{\circ} \mathrm{C}\right)$ in the Mediterranean Sea. Although most recordings were obtained in the summer, seawater temperatures ranged from $14.3^{\circ} \mathrm{C}$ to $29.0^{\circ} \mathrm{C}$ (YapıCl, 2018). In this study, the individual was observed in the period when the water temperature was high. Nonetheless, the more widespread colonization of the Mediterranean and Aegean region by $P$. miles seems no temperature-dependent. Further studies should focus on the interaction between lionfishes and seasonal water temperature variation in order to better understand whether temperature.

Lionfish are usually distributed in tropical marine waters, and have been found on hard bottoms, mangroves, sea grass, coral, and artificial reef communities (Gomez et al., 2013). In their original habitats, they occur along coral reefs and rocky shores down to depth of $50 \mathrm{~m}$ (Froese and Pauly, 2019). All records from various parts of the Mediterranean Sea report this species generally from depths of 2-110 m (Bariche et al., 2013; Oray et al., 2015; Kletou et al., 2016; Bilge et al., 2017; Yapıcı, 2018). Characteristics such as location, date, total length, observation method, habitat type and depth were obtained from peer-viewed publications to examine the journey of the species in the Mediterranean Sea (Figure 2; Table.2).

Table 2. The journey of $P$. miles from the Mediterranean Sea to the Aegean Sea (The number in front of each locality was shown in Figure 2)

\begin{tabular}{|c|c|c|c|c|c|c|c|}
\hline No & Location & Coordinates & $\begin{array}{l}\text { Length Range } \\
\text { (TL mm) }\end{array}$ & Habitat & Depth (m) & Observation Method & Reference \\
\hline 1 & Herzliya, Israel & - & 328 & - & 35 & Trawl & Golani \& Sonin, 1992 \\
\hline 2 & Al Minie, Lebanon & $34.29 \mathrm{~N} 35.54 \mathrm{E}$ & 209 & Coralligenous & 30 & Gill net & Bariche et al., 2013 \\
\hline 3 & İskenderun, Turkey & $36.17 \mathrm{~N} 35.46 \mathrm{E}$ & 276 & Rocky bottom & 25 & - & Turan et al., 2014 \\
\hline 4 & Rhodes, Greece & $36.38 \mathrm{~N} 28.24 \mathrm{E}$ & - & Rocky bottom & 7 & Diving & Crocetta et al., 2015 \\
\hline 5 & Rhodes, Greece & $35.91 \mathrm{~N} 27.85 \mathrm{E}$ & - & Shipwreck & - & Diving & Crocetta et al., 2015 \\
\hline 6 & Rhodes, Greece & $36.45 \mathrm{~N} 28.21 \mathrm{E}$ & - & Rocky bottom & 2 & Diving & Crocetta et al., 2015 \\
\hline 7 & Ormidia, Cyprus & - & 170 & - & 10 & Gill net & Iglesias \& Frotte, 2015 \\
\hline 8 & Karpas, Cyprus & - & 373 & Rocky bottom & 40 & Gill net & Oray et al., 2015 \\
\hline 9 & Dalyan, Turkey & - & - & Sandy bottom & 11 & Diving & Turan \& Öztürk, 2015 \\
\hline 10 & NE Crete, Greece & $35.20 \mathrm{~N} 26.30 \mathrm{E}$ & 250 & Rocky bottom & 33 & Gill net & Daillianis et al., 2016 \\
\hline 11 & SE Crete, Greece & $35.01 \mathrm{~N} 25.96 \mathrm{E}$ & 100 & Rocky bottom & $12-37$ & - & Daillianis et al., 2016 \\
\hline 12 & Karpathos Island, Greece & $35.55 \mathrm{~N} 27.20 \mathrm{E}$ & 100 & Rocky bottom & 17 & Diving & Mytilineou et al., 2016 \\
\hline 13 & Karpathos Island, Greece & $35.50 \mathrm{~N} 27.22 \mathrm{E}$ & 200 & Rocky bottom & 16 & Diving & Mytilineou et al., 2016 \\
\hline 14 & Mersin, Turkey & $36.08 \mathrm{~N}-33.40 \mathrm{E}$ & 250 & - & $100-110$ & Trawl & Yağlıoğlu \& Ayas, 2016 \\
\hline 15 & Kemer, Turkey & - & $85-293$ & Rocky Bottom & $10-15$ & Spearfishing & Özgür-Özbek et al., 2017 \\
\hline 16 & Didim-Aydın, Turkey & $37.20 \mathrm{~N} 27.14 \mathrm{E}$ & - & Rocky bottom & 18 & Diving & Yapıcı, 2018 \\
\hline $17^{*}$ & Kokar Bay, Turkey & $38.13 \mathrm{~N} 26.61 \mathrm{E}$ & 144 & Rocky bottom & 15 & Spearfishing & Present study \\
\hline
\end{tabular}


Top predators are very important to decrease lionfishes populations that indicate conservation of top predators to struggle lionfishes. Lionfish have very few documented natural predators due to their venomous spines. Grouper species such as dusky grouper Epinephelus marginatus, goldblotch grouper Ephinephelus costae and blue-spotted cornetfish Fistularia commersonii are the main predators of the lionfishes (Bernadsky and Goulet, 1991; Maljković et al., 2008; Turan et al., 2017). Especially groupers of these species, as these may, may help control the spread of invasive fish (Mumby et al., 2011; Kletou et al., 2016). However, illegal fishing pressure on these species should be controlled in the Mediterranean and the Aegean Sea. Since fishing activities such as trawling and purse seiner and also trammel nets do not the solution to struggle lionfish, which usually inhabit under big rocks and caves. Therefore, predators of lionfish need to be supported in this struggle. Countries in the Mediterranean Sea organize campaigns and spearfishing competitions to eradicate lionfish

\section{REFERENCES}

Al Mabruk, S.A.A. \& Rizgala, J. (2019). First record of lionfish (Scorpaenidae: Pterois) from Libyan waters. Journal of Black Sea/Mediterranean Environment, 25(1), 108-114.

Azzurro, E. \& Bariche, M. (2017). Local knowledge and awareness on the incipient lionfish invasion in the eastern Mediterranean Sea. Marine and Freshwater Research, 68(10), 1950-1954. DOI: 10.1071/mf16358

Bariche, M., Torres, M. \& Azzurro, E. (2013). The Presence of the invasive Lionfish Pterois miles in the Mediterranean Sea. Mediterranean Marine Science, 14(2), 292. DOI: 10.12681/mms.428

Bernadsky, G. \& Goulet, D. (1991). A natural predator of the lionfish Pterois miles. Copeia, 1991, 230-231.

Bilecenoğlu, M. (2018). Controlling the lionfish invasion in the eastern Mediterranean Sea. In Hüseyinoğlu, M.F., \& Öztürk, B. (Eds.), Lionfish Invasion and Its Management in the Mediterranean Sea (pp:1-9). Turkish Marine Research Foundation (TUDAV) Publication no: 49, Istanbul, Turkey. $121 \mathrm{pp}$.

Bilge, G., Filiz, H., Yapıcı, S. \& Gülşahin, A. (2016). On the occurrence of the devil firefish Pterois miles (Scorpaenidae), from the southern Aegean Sea with an elaborate occurrences in the Mediterranean coast of Turkey. Hydromedit, 2nd International Congress on Applied Ichthyology \& Aquatic Environment. 10 - 12 November 2016, Messolonghi, Greece. Book of Proceedings pp: 324-327.

Bilge, G., Filiz, H. \& Yapıcı, S. (2017). Occurrences of Pterois miles (Bennett, 1828) between 1992 and 2016 from Turkey and the Mediterranean Sea. Journal of Black Sea/Mediterranean Environment, 23(3): 201-208.

Bilge, G., Filiz, H., Yapıcı, S., Tarkan, A.S. \& Vilizzi, L. (2019). A risk screening study on the potential invasiveness of Lessepsian fishes in the southwestern coasts of Anatolia. Acta Ichthyologica et Piscatoria, 49(1), 23-31. DOI: 10.3750/AIEP/02422

Crocetta, F., Agius, D., Balistreri, P., Bariche, M., Bayhan, Y., Çakır, M., Ciriaco, S., Corsini-Foka, M., Deidun, A., El Zrelli, R., Ergüden, D., Evans, J., Ghelia, M., Giavasi, M., Kleitou, P., Kondylatos, G., Lipej, L., Mifsud, C., Özvarol, Y., Pagano, A., Portelli, P., Poursanidis, D., Rabaoui, L., Schembri, P., Taşkın, E., Tiralongo, F. \& Zenetos, A. (2015). New Mediterranean Biodiversity Records (October 2015). Mediterranean Marine Science, 16(3), 682-702. DOI: 10.12681/mms.1477

Dabruzzi, T., Bennett, W. \& Fangue, N. (2017). Thermal ecology of red lionfish Pterois volitans from southeast Sulawesi, Indonesia, with comparisons to other Scorpaenidae. Aquatic Biology, 26, 1-14. DOI: 10.3354/ab00668

Dailianis, T., Akyol, O., Babalı, N., Bariche, M., Crocetta, F., Gerovasileiou, V., Chanem, R., Gökoğlu, M., Hasiotis, T., Izquierdo-Muñoz, A., Julian, D., Katsanevakis, S., Lipez, L., Mancini, E., Mytilineou, C., Ounifi Ben Amor, and also encourage of human consumption (Bilecenoğlu, 2018). However, some researchers point out that complete eradication of lionfish is impossible; these organizations only may help to keep their population under control and protect the native marine ecosystems.

In conclusion, the status of $P$. miles in the Mediterranean and adjacent seas should be monitored closely via formal and citizen sciences. The recent and rapid expansion of the $P$. miles in the Mediterranean is therefore alarming and requires the immediate action of all concerned stakeholders in the area (Bariche et al., 2017). Finally, it is vital that the ecology and distribution of the invasive species are fully understood to design the most effective form of control.

\section{ACKNOWLEDGMENT}

Author would like to thank Gökay Gülhep for his help in providing this specimen.

K., Özgül, A., Ragkousis, M., Rubio-Portillo, E., Servello, G., Sini, K., Stamouli, C., Sterioti, A., Teker, S., Tiralongo, F. \& Trkov, D. (2016). New Mediterranean Biodiversity Records (July 2016). Mediterranean Marine Science, 17(2), 608-626. DOI: 10.12681/mms.1734

Evripidou, S. (2013). Toxic Lionfish makes its way to Cyprus waters. http://www.cyprus-mail.com/cyprus/toxic-Lionfishmakes-its-way-cypruswaters/20130220. (Accessed 22 February 2013)

Filiz, H., Tarkan, A.S., Bilge, G. \& Yapıcı, S. (2017). Assessment of invasiveness potential of Pterois miles by the Aquatic Species Invasiveness Screening Kit. Journal of Black Sea/Mediterranean Environment. 23(1):17-37.

Froese, R. \& Pauly, D. (2019). FishBase. World Wide Web electronic publication. www. fishbase.org, version (10/2019).

Giovos, I., Kletou, P., Paravas, P., Marmara, D., Romanidis-Kyriakidis, G. \& Poursanidis, D. (2018). Citizen scientists monitoring the establishment and expansion of Pterois miles (Bennett, 1828) in the Aegean Sea, Greece. Cahiers de Biologie Marine, 59, 359-365. DOI: 10.21411/CBM.A.8DFA67CE

Golani, D. \& Sonin, O. (1992). New records of the Red Sea fishes, Pterois miles (Scorpaenidae) and Pteragogus pelycus (Labridae) from the eastern Mediterranean Sea. Japanese Journal of Ichthyology, 39(2), 167169.

Golani, D., Öztürk, B. \& Başusta, N. (2006). Fishes of the eastern Mediterranean. Turkish Marine Research Foundation. Pub. Number: 24. Istanbul, Turkey. 259 pp.

Gomez, L.R., Anderson, J.L., Akins, D.S.A., Buddo, G., Garcia-Moliner, F., Gourdin, M., Laurent, C., Lilyestrom, J.A., Morris, J., Ramnanan, N. \& Torres, R. (2013). Regional strategy for the control of invasive lionfish in the wider Caribbean. International Coral Reef Initiative, $31 \mathrm{pp}$.

Green, S.J. \& Côté, I.M. (2009). Record densities of Indo-Pacific Lionfish on Bahamian coral reefs. Coral Reefs, 28, 107-107 DOI: $10.1007 / \mathrm{s} 00338-008-0446-8$

Hare, J.A. \& Whitfield, P.E. (2003). An integrated assessment of the introduction of lionfish (Pterois volitans/miles complex) to the western Atlantic Ocean. NOAA Technical Memorandum NOS NCCOS 2, 21 pp.

Iglésias, S. \& Frotté, L. (2015). Alien marine fishes in Cyprus: update and new records. Aquatic Invasions, 10(4), 425-438. DOI: 10.3391/ai.2015.10.4.06

Jimenez, C., Petrou, A., Andreou, V., Hadjioannou, L., Wolf, W., Koutsoloukas, N. \& Abu Alhaija, R. (2016). Veni, vidi, vici: The successful establishment of the lionfish Pterois miles in Cyprus (Levantine Sea). Rapp Comm int Mer Médit, 41, 417 
Karachle, P.K., Zenetos, A. \& Xentidis, N.J. (2017). The Esenias Countries' Marine Alien Species Experts: An Updated Inventory. Acta Zoologica Bulgarica, 9, 261-282

Katsanevakis, S., Coll, M., Piroddi, C., Steenbeek, J., Lasram, B.R.F., Zenetos, A. \& Cardoso, A.C. (2014). Invading the Mediterranean Sea: Biodiversity patterns shaped by human activities. Frontiers in Marine Science, 1, 32 DOI: 10.3389/fmars.2014.00032

Kimball, M., Miller, J., Whitfield, P. \& Hare, J. (2004). Thermal tolerance and potential distribution of invasive lionfish (Pterois volitans/ miles complex) on the east coast of the United States. Marine Ecology Progress Series, 283, 269-278. DOI: 10.3354/meps283269

Kletou, D., Hall-Spencer, J.M. \& Kleitou, P. (2016). A lionfish (Pterois miles) invasion has begun in the Mediterranean Sea. Marine Biodiversity Records, 9(1), 46 DOI: 10.1186/s41200-016-0065-y

Lejeusne, C., Chevaldonné, P., Pergent-Martini, C., Boudouresque, C.F. \& Perez, T. (2010). Climate change effects on a miniature ocean: the highly diverse, highly impacted Mediterranean Sea. Trends in Ecology and Evolution, 25(4), 250-60. DOI: 10.1016/j.tree.2009.10.009

Maljković, A., Van Leeuwen, T. \& Cove, S. (2008). Predation on the invasive red lionfish, Pterois volitans (Pisces: Scorpaenidae), by native groupers in the Bahamas. Coral Reefs, 27, 501. DOI: 10.1007/s00338-008-0372-9

Montefalcone, M., Morri, C, Parravicini, V. \& Bianchi, C.N. (2015). A tale of two invaders: divergent spreading kinetics of the alien green algae Caulerpa taxifolia and Caulerpa cylindracea. Biological Invasions, 17, 2717-2728.

Mumby, P.J., Hardborne, A.R. \& Brumbaugh, D.R. (2011). Grouper as a natural biocontrol of invasive lionfish. PLoS ONE 6(6): e21510. DOI: $10.1371 /$ journal.pone.0021510

Mytilineou, C., Akel, E.K., Babalı, N., Balistreri, P., Bariche, M., Boyacı, Y.O. Cilenti, L., Constantinou, C., Crocetta, F., Çelik, M., Dereli, H., Dounas, C., Durucan, F., Garrido, A., Gerovasileiou, V., Kapiris, K., Kebapcioglu, T., Kleitou, P., Krystalas, A., Lipej, L., Maina, I., Marakis, P., Mavrič, B. Moussa, R., Peña-Rivas, L., Poursanidis, D., Renda, W., Rizkalla, S.I., Rosso, A., Scirocco, T., Sciuto, F., Servello, G., Tiralongo, F., Yapıcı, S.
\& Zenetos, A. (2016). New Mediterranean biodiversity records (November, 2016). Mediterranean Marine Science, 17(3), 794-821.

DOI: $10.12681 / \mathrm{mms} .1976$

Oray, I.K., Sınay, E., Karakulak, F.S. \&Yıldız, T. (2015). An expected marine alien fish caught at the coast of Northern Cyprus: Pterois miles (Bennett, 1828). Journal of Applied Ichthyology, 31 (4), 733-735.

DOI: 10.1111/jai.12857

Özgür-Özbek, E., Mavruk, S., Saygu, İ. \& Öztürk, B. (2017). Lionfish distribution in the eastern Mediterranean coast of Turkey. Journal of the Black Sea/Mediterranean Environment, 23(1), 1-16.

Poursanidis, D. (2015). Ecological Niche Modeling of the the invasive lionfish Pterois miles (Bennett, 1828) in the Mediterranean Sea. In Eleventh Panhellenic Symposium on Oceanography and Fisheries ( $p: 621-624)$. Mytilene, Lesvos Island, Greece.

Turan, C., Ergüden, D., Gürlek, M., Yağlıoğlu, D., Uyan, A. \& Uygur, N. (2014). First record of the Indo-Pacific lionfish Pterois miles (Bennett, 1828) (Osteichthyes: Scorpaenidae) for the Turkish marine waters. Journal of the Black Sea/Mediterranean Environment, 20, 158-163.

Turan, C. \& Öztürk, B. (2015). First record of the lionfish Pterois miles from the Aegean Sea. Journal of the Black Sea/Mediterranean Environment, 21, 334-338.

Turan, C., Ergüden, D. \& Gürlek, M. (2016). Climate change and biodiversity effects in Turkish Seas. Natural and Engineering Sciences, 1(2), 15-24.

Turan, C., Uygur, N. \& İğde, M. (2017). Lionfishes Pterois miles and Pterois volitans in the North-eastern Mediterranean Sea: Distribution, habitation, predation and predators. Natural and Engineering Sciences, 2(1), 35-43.

Yağlığlu, D. \& Ayas, D. (2016). New occurrence data of four alien fishes (Pisodonophis semicinctus, Pterois miles, Scarus ghobban and Parupeneus forsskali) from the North Eastern Mediterranean (Yeşilovacık Bay, Turkey). Biharean Biologist, 10 (2), 150-152.

Yapıcı, S. (2018). Piscis non grata in the Mediterranean Sea: Pterois miles (Bennett, 1828). Ege Journal of Fisheries and Aquatic Sciences, 35(4), 467-474. DOI: 10.12714/egejfas.2018.35.4.13 